\title{
Melioidosis of the Musculoskeletal System
}

\author{
Rajamani Perumal Abel Livingston Sumant Samuel \\ Santhosh Kumar Govindaraju \\ Department of Orthopaedics, Christian Medical College, Vellore, India
}

\section{Significance of the Study}

- We aimed to describe the clinical presentation of Burkholderia pseudomallei infection of the musculoskeletal system as it is under-reported in the literature.

- Out of 342 (9.2\%) patients with B. pseudomallei infection, 37 had musculoskeletal involvement in our series of melioidosis.

- We present the varied surgical treatment modalities used in addition to medical management that resulted in resolution of disease in all our patients.

\section{Keywords}

Burkholderia psuedomallei · Melioidosis .

Musculoskeletal system

\section{Abstract}

Objective: Recent studies indicate that India is an endemic region for Burkholderia pseudomallei infection. We aimed to describe the clinical presentation of B. pseudomallei infection of the musculoskeletal system and summarise the various treatment modalities used in our clinical practice. Subjects and Methods: Patients with confirmed microbiological diagnosis of $B$. pseudomallei infection involving the musculoskeletal system treated from January 2007 to December 2016 with a minimum follow-up of 1 year were included. A retrospective review of medical records was carried out and patients' demographic data, co-morbidities, clinical presentation, and details of medical and surgical treatment were documented. Results: Of 342 patients diagnosed with $B$. pseudomallei infection, 37 (9.2\%) had musculoskeletal involvement; 26 patients ( 23 males) followed up for at least a year were included in the study. Four patients (15\%) had multisystem involvement and $10(37 \%)$ had multiple musculoskeletal foci of infection; 15 patients (58\%) had osteomy- elitis, 10 (38\%) had septic arthritis with or without osteomyelitis, and 1 patient (4\%) presented with only soft tissue abscess. All patients required surgical intervention in addition to medical management. Surgical treatment varied from soft tissue abscess drainage, arthrotomy for septic arthritis, decompression and curettage for osteomyelitis, and/or use of antibiotic (meropenem or ceftazidime)-loaded polymethylmethacrylate bone cement for local drug delivery. At final follow-up (average: 37 months, range: 12-120), all patients were disease free. Conclusion: We found the rate of musculoskeletal involvement in B. pseudomallei infection to be 9.2\%. Appropriate surgical treatment in addition to medical management resulted in resolution of disease in all our patients.

(c) 2019 The Author(s) Published by S. Karger AG, Basel

\section{Introduction}

Melioidosis is caused by the Gram-negative bacterium Burkholderia pseudomallei [1]. It was first described by Whitmore and Krishnaswami [1] and is mainly present in southeast Asia and northern Australia [1,2]. It was first reported in India in 1990, and India has been recently

\begin{tabular}{ll}
\hline KARGER & $\begin{array}{l}\text { (c) } 2019 \text { The Author(s) Karger } \\
\text { Published by S. Karger AG, Basel }\end{array}$ \\
karger@karger.com & $\begin{array}{l}\text { This is an Open Access article licensed under the Creative Commons } \\
\text { Attribution-NonCommercial-4.0 International License (CC BY-NC) } \\
\text { (http://www.karger.com/Services/OpenAccessLicense), applicable to } \\
\text { the online version of the article only. Usage and distribution for com- } \\
\text { mercial purposes requires written permission. }\end{array}$
\end{tabular}

Abel Livingston

Department of Orthopaedics, Christian Medical College

Ida Scudder Road

Vellore, Tamil Nadu 632004 (India)

E-Mail livings78@gmail.com 


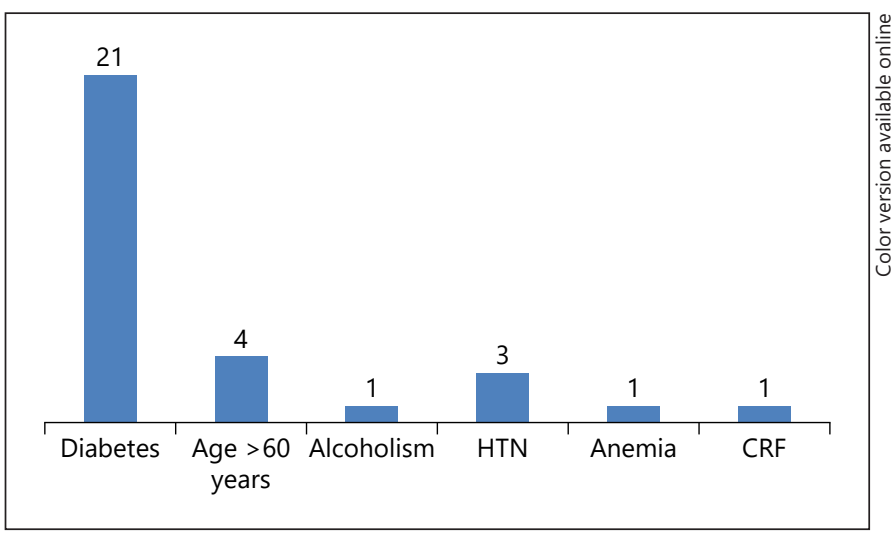

Fig. 1. Comorbidities in patients with melioidosis. HTN, hypertension; CRF, chronic renal failure.

recognised as an endemic zone $[2,3]$. This infection is transmitted through direct contact, cutaneous inoculation, inhalation, or ingestion, and patients clinically exhibit abscesses in single or multiple organs $[4,5]$. This infection is clinically under-reported due to a low index of suspicion, lack of diagnostic facilities, and misdiagnosis as tuberculosis [6]. An increase in reports from India has been noted since the beginning of this millennium because of increased awareness and improved diagnostic modalities [7]. Herein, we describe the clinical presentation of $B$. pseudomallei infection of the musculoskeletal system and summarise the varied surgical treatment modalities used in addition to medical management in our practice.

\section{Patients and Methods}

The inclusion criteria for our study were patients diagnosed with $B$. pseudomallei infection involving the musculoskeletal system treated at our institution between 2007 and 2016 and followed up for a minimum of 1 year. Patients with multisystem involvement were included in the study if the musculoskeletal system was also involved. Patients with less than a 1-year follow-up were excluded from the study. Patient information was collected from electronic outpatient records, inpatient records, discharge summaries, and medical reports. Patient demographic data, comorbidities, clinical manifestations, and medical and surgical treatment details were documented.

The diagnosis was microbiologically confirmed in all patients. $B$. pseudomalle $i$ is a non-fermenting Gram-negative bacillus showing bipolar staining on Gram stain. It produces non-haemolytic greyish-white colonies on blood agar plates and non-lactose fermenting colonies on MacConkey agar. The organism is motile, oxidase positive, resistant to gentamicin and colistin, indole negative, and citrate negative. Alkaline slant/alkaline butt with no gas production is seen on triple sugar iron agar [8]. Colonies on culture plates with the above-mentioned characteristics were tested in our laboratory using $B$. pseudomallei-specific antisera raised in rabbits and agglutination of the suspected colonies with antisera aids in presumptive identification of the organism. Biochemical confirmation of the same was performed using the nitrate reduction test, gelatine liquefaction, and arginine dihydrolase activity which showed positive results, and the arabinose assimilation test which showed a negative result [8]. Antimicrobial susceptibility testing was performed as per guidelines of the Clinical Laboratory Standards Institute (CLSI) [9].

Descriptive statistics were used to analyse the results. Categorical variables were presented as raw values and percentages of study sample whereas continuous variables were presented as averages and ranges.

\section{Results}

A review of medical records revealed that 342 patients were diagnosed with $B$. pseudomallei infection between January 2007 and December 2016. Of these 342 patients, $37(9.2 \%)$ had musculoskeletal infection. One patient with septic arthritis of the knee and multisystemic involvement (parotid abscess and pulmonary infection) died in the hospital due to septicaemic shock. A total of 26 patients (70\%), 23 males and 3 females, followed up for at least 1 year were included in this study. The average age of the patients was 47 years (range: 21-69). The duration of symptoms was less than 6 weeks in 10 patients (38\%) and more than 6 weeks in $16(62 \%)$.

At least one comorbidity was present in 20 patients (77\%) and multiple comorbidities in 6 patients (23\%) (Fig. 1). Diabetes was the most common comorbidity (20 patients, $77 \%)$. $\mathrm{HbA}_{1 \mathrm{c}}$ levels were documented for $20 \mathrm{pa}$ tients $(77 \%)$, of whom $14(70 \%)$ had $\mathrm{HbA}_{1 \mathrm{c}}$ levels of more than $6.5[10]$.

Blood cultures were performed for 13 patients (50\%) and were positive for B. pseudomallei infection in 6 patients (23\%). Three patients (11.5\%) had evidence of $B$. pseudomallei infection in other systems (pulmonary infection, hepatic abscess, and splenic abscess).

The most common musculoskeletal site of infection was the femur (12 patients, $46 \%$ ) (Table 1). Multiple musculoskeletal foci of infection was seen in 8 patients (30\%). Osteomyelitis was seen in 15 patients (58\%), septic arthritis with or without osteomyelitis in 10 patients (38\%), and soft tissue abscess in 1 patient (4\%).

The average follow-up duration was 41 months (range: 12-120). All patients received a course of injectable ceftazidime, followed by a course of oral doxycycline and/ or co-trimoxazole. The exact duration of injectable and oral therapy was based on the clinical resolution of symptoms and was decided by the treating physicians. 
Table 1. Clinical details of patients with musculoskeletal Burkholderia pseudomallei infection (melioidosis) included in the study

\begin{tabular}{|c|c|c|c|c|c|c|c|c|c|c|c|}
\hline $\begin{array}{l}\text { Patient } \\
\text { No. }\end{array}$ & $\begin{array}{l}\text { Age, } \\
\text { years }\end{array}$ & Sex & $\begin{array}{l}\text { Multisystemic } \\
\text { involvement }\end{array}$ & MSK foci & $\begin{array}{l}\text { Duration, } \\
\text { days }\end{array}$ & Blood culture & Surgical treatment & Surgeries, $n$ & $\begin{array}{l}\text { Antibiotic } \\
\text { treatment }\end{array}$ & $\begin{array}{l}\text { Antibiotic } \\
\text { duration }\end{array}$ & $\begin{array}{l}\text { Follow-up, } \\
\text { months }\end{array}$ \\
\hline 1 & 60 & M & - & Femur & 30 & - & $\begin{array}{l}\text { 1. Decompression and } \\
\text { curettage } \\
\text { 2. Antibiotic PMMA } \\
\text { beads }\end{array}$ & 3 & $\begin{array}{l}\text { 1. Ceftazidime } \\
\text { 2. Co-trimoxazole } \\
\text { 3. Doxycycline }\end{array}$ & $\begin{array}{l}11 \text { days } \\
10 \text { weeks }\end{array}$ & 48 \\
\hline 2 & 52 & M & - & Tibia & 45 & - & $\begin{array}{l}\text { 1. Decompression and } \\
\text { curettage } \\
\text { 2. Antibiotic PMMA } \\
\text { beads }\end{array}$ & 2 & $\begin{array}{l}\text { 1. Ceftazidime } \\
\text { 2. Co-trimoxazole }\end{array}$ & $\begin{array}{l}8 \text { days } \\
18 \text { weeks }\end{array}$ & 20 \\
\hline 3 & 37 & M & - & $\begin{array}{l}\text { Femur } \\
\text { Tibia }\end{array}$ & 90 & - & $\begin{array}{l}\text { 1. Soft tissue abscess } \\
\text { drainage, arthrotomy, } \\
\text { and drainage } \\
\text { 2. Decompression and } \\
\text { curettage }\end{array}$ & 1 & $\begin{array}{l}\text { 1. Ceftazidime } \\
\text { 2. Doxycycline }\end{array}$ & $\begin{array}{l}6 \text { weeks } \\
30 \text { weeks }\end{array}$ & 12 \\
\hline 4 & 58 & M & - & Femur & 30 & - & $\begin{array}{l}\text { Decompression and } \\
\text { curettage }\end{array}$ & 1 & $\begin{array}{l}\text { 1. Ceftazidime } \\
\text { 2. Doxycycline }\end{array}$ & $\begin{array}{l}10 \text { days } \\
26 \text { weeks }\end{array}$ & 60 \\
\hline 5 & 29 & $\mathrm{~F}$ & - & $\begin{array}{l}\text { Thigh } \\
\text { Knee }\end{array}$ & 45 & & $\begin{array}{l}\text { Soft tissue abscess } \\
\text { drainage, arthrotomy, } \\
\text { and drainage }\end{array}$ & 1 & $\begin{array}{l}\text { 1. Ceftazidime } \\
\text { 2. Co-trimoxazole } \\
\text { 3. Doxycycline }\end{array}$ & $\begin{array}{l}\text { Details } \\
\text { not available }\end{array}$ & 84 \\
\hline 6 & 69 & M & - & $\begin{array}{l}\text { Knee } \\
\text { Leg }\end{array}$ & 15 & - & $\begin{array}{l}\text { Soft tissue abscess } \\
\text { drainage, arthrotomy, } \\
\text { and drainage }\end{array}$ & 1 & $\begin{array}{l}\text { 1. Ceftazidime } \\
\text { 2. Doxycycline }\end{array}$ & $\begin{array}{l}19 \text { days } \\
37 \text { weeks }\end{array}$ & 36 \\
\hline 7 & 62 & M & - & Ankle & 30 & & $\begin{array}{l}\text { Arthrotomy, drainage, } \\
\text { and soft tissue abscess } \\
\text { drainage }\end{array}$ & 1 & $\begin{array}{l}\text { 1. Ceftazidime } \\
\text { 2. Co-trimoxazole } \\
\text { 3. Doxycycline }\end{array}$ & $\begin{array}{l}7 \text { days } \\
14 \text { weeks } \\
27 \text { weeks }\end{array}$ & 26 \\
\hline 8 & 38 & M & - & Femur & 16 & Positive & $\begin{array}{l}\text { Decompression and } \\
\text { curettage }\end{array}$ & 1 & $\begin{array}{l}\text { 1. Ceftazidime } \\
\text { 2. Co-trimoxazole } \\
\text { 3. Doxycycline }\end{array}$ & $\begin{array}{l}6 \text { weeks } \\
25 \text { weeks }\end{array}$ & 26 \\
\hline 9 & 40 & M & - & Tibia & 2,555 & - & $\begin{array}{l}\text { Decompression and } \\
\text { curettage }\end{array}$ & 1 & $\begin{array}{l}\text { 1. Ceftazidime } \\
\text { 2. Co-trimoxazole }\end{array}$ & $\begin{array}{l}\text { Details } \\
\text { not available }\end{array}$ & 26 \\
\hline 10 & 62 & $\mathrm{~F}$ & - & Knee & 14 & Negative & $\begin{array}{l}\text { Arthrotomy and } \\
\text { drainage }\end{array}$ & 2 & Ceftazidime & 13 days & 16 \\
\hline 11 & 47 & M & - & Humerus & 45 & Negative & $\begin{array}{l}\text { Decompression and } \\
\text { curettage }\end{array}$ & 1 & $\begin{array}{l}\text { 1. Ceftazidime } \\
\text { 2. Doxycycline } \\
\text { 3. Co-trimoxazole }\end{array}$ & $\begin{array}{l}15 \text { days } \\
24 \text { weeks } \\
40 \text { weeks }\end{array}$ & 12 \\
\hline 12 & 45 & M & - & $\begin{array}{l}\text { Knee } \\
\text { Leg }\end{array}$ & 60 & Negative & $\begin{array}{l}\text { Arthrotomy and } \\
\text { drainage }\end{array}$ & 1 & $\begin{array}{l}\text { 1. Ceftazidime } \\
\text { 2. Doxycycline } \\
\text { 3. Co-trimoxazole }\end{array}$ & $\begin{array}{l}25 \text { days } \\
12 \text { weeks } \\
30 \text { weeks }\end{array}$ & 12 \\
\hline 13 & 38 & M & - & Femur & 21 & - & $\begin{array}{l}\text { 1. Soft tissue abscess } \\
\text { drainage, arthrotomy, } \\
\text { and drainage } \\
\text { 2. Decompression and } \\
\text { curettage } \\
\text { 3. Antibiotic beads }\end{array}$ & 3 & $\begin{array}{l}\text { 1. Ceftazidime } \\
\text { 2. Co-trimoxazole } \\
\text { 3. Doxycycline }\end{array}$ & $\begin{array}{l}6 \text { weeks } \\
22 \text { weeks } \\
10 \text { days }\end{array}$ & 24 \\
\hline 14 & 40 & M & - & Shoulder & 30 & - & $\begin{array}{l}\text { Arthrotomy and } \\
\text { drainage }\end{array}$ & 1 & $\begin{array}{l}\text { 1. Ceftazidime } \\
\text { 2. Doxycycline }\end{array}$ & $\begin{array}{l}4 \text { weeks } \\
12 \text { weeks }\end{array}$ & 30 \\
\hline 15 & 33 & M & - & $\begin{array}{l}\text { Femur } \\
\text { Hip }\end{array}$ & 60 & Positive & $\begin{array}{l}\text { 1. Soft tissue abscess } \\
\text { drainage, arthrotomy, } \\
\text { and drainage } \\
\text { 2. Decompression and } \\
\text { curettage }\end{array}$ & 2 & $\begin{array}{l}\text { 1. Meropenem } \\
\text { 2. Ceftazidime } \\
\text { 3. Doxycycline }\end{array}$ & $\begin{array}{l}10 \text { days } \\
22 \text { weeks } \\
23 \text { weeks }\end{array}$ & 24 \\
\hline 16 & 36 & M & - & $\begin{array}{l}\text { Femur } \\
\text { Tibia } \\
\text { Ankle }\end{array}$ & 30 & Negative & $\begin{array}{l}\text { 1. Soft tissue abscess drainage } \\
\text { 2. Arthrotomy and } \\
\text { drainage } \\
\text { 3. Decompression } \\
\text { and curettage } \\
\text { 4. Antibiotic beads }\end{array}$ & 3 & $\begin{array}{l}\text { 1. Ceftazidime } \\
\text { 2. Doxycycline } \\
\text { 3. Co-trimoxazole }\end{array}$ & $\begin{array}{l}6 \text { weeks } \\
3 \text { weeks } \\
21 \text { weeks }\end{array}$ & 30 \\
\hline 17 & 57 & M & - & Tibia & 150 & - & $\begin{array}{l}\text { 1. Decompression and } \\
\text { curettage } \\
\text { 2. Antibiotic beads }\end{array}$ & 1 & $\begin{array}{l}\text { 1. Ceftazidime } \\
\text { 2. Co-trimoxazole }\end{array}$ & $\begin{array}{l}6 \text { weeks } \\
27 \text { weeks }\end{array}$ & 12 \\
\hline 18 & 53 & $\mathrm{~F}$ & - & Femur & 60 & - & $\begin{array}{l}\text { Soft tissue abscess } \\
\text { drainage, arthrotomy, } \\
\text { and drainage }\end{array}$ & 1 & $\begin{array}{l}\text { 1. Ceftazidime } \\
\text { 2. Co-trimoxazole }\end{array}$ & $\begin{array}{l}4 \text { weeks } \\
140 \text { weeks }\end{array}$ & 12 \\
\hline 19 & 42 & M & - & Tibia & 45 & Positive & $\begin{array}{l}\text { Decompression and } \\
\text { curettage }\end{array}$ & 2 & $\begin{array}{l}\text { 1. Ceftazidime } \\
\text { 2. Co-trimoxazole } \\
\text { 3. Doxycycline }\end{array}$ & $\begin{array}{l}7 \text { weeks } \\
13 \text { weeks } \\
3 \text { days }\end{array}$ & 12 \\
\hline 20 & 42 & M & - & Femur & 120 & Positive & Antibiotic beads & 2 & $\begin{array}{l}\text { 1. Ceftazidime } \\
\text { 2. Doxycycline } \\
\text { 3. Co-trimoxazole }\end{array}$ & $\begin{array}{l}8 \text { weeks } \\
33 \text { weeks } \\
48 \text { weeks }\end{array}$ & 39 \\
\hline
\end{tabular}


Table 1 (continued)

\begin{tabular}{|c|c|c|c|c|c|c|c|c|c|c|c|}
\hline $\begin{array}{l}\text { Patient } \\
\text { No. }\end{array}$ & $\begin{array}{l}\text { Age, } \\
\text { years }\end{array}$ & Sex & $\begin{array}{l}\text { Multisystemic } \\
\text { involvement }\end{array}$ & MSK foci & $\begin{array}{l}\text { Duration, } \\
\text { days }\end{array}$ & Blood culture & Surgical treatment & Surgeries, $n$ & $\begin{array}{l}\text { Antibiotic } \\
\text { treatment }\end{array}$ & $\begin{array}{l}\text { Antibiotic } \\
\text { duration }\end{array}$ & $\begin{array}{l}\text { Follow-up, } \\
\text { months }\end{array}$ \\
\hline 21 & 50 & M & - & Femur & 45 & Negative & $\begin{array}{l}\text { Decompression and } \\
\text { curettage }\end{array}$ & 1 & $\begin{array}{l}\text { 1. Ceftazidime } \\
\text { 2. Doxycycline } \\
\text { 3. Co-trimoxazole }\end{array}$ & $\begin{array}{l}6 \text { weeks } \\
20 \text { weeks } \\
20 \text { weeks }\end{array}$ & 84 \\
\hline 22 & 54 & M & - & Femur & 19 & Negative & $\begin{array}{l}\text { Decompression and } \\
\text { curettage }\end{array}$ & 2 & $\begin{array}{l}\text { 1. Ceftazidime } \\
\text { 2. Doxycycline } \\
\text { 3. Co-trimoxazole }\end{array}$ & $\begin{array}{l}7 \text { weeks } \\
44 \text { weeks } \\
87 \text { weeks }\end{array}$ & 60 \\
\hline 23 & 53 & M & $\begin{array}{l}\text { Liver } \\
\text { Spleen }\end{array}$ & Tibia & 15 & Negative & $\begin{array}{l}\text { Decompression and } \\
\text { curettage }\end{array}$ & 1 & $\begin{array}{l}\text { 1. Ceftazidime } \\
\text { 2. Co-trimoxazole } \\
\text { 3. Doxycycline }\end{array}$ & $\begin{array}{l}3 \text { weeks } \\
5 \text { months } \\
5 \text { months }\end{array}$ & 84 \\
\hline 24 & 25 & M & $\begin{array}{l}\text { Lungs } \\
\text { Hepatospleeno- } \\
\text { megaly }\end{array}$ & $\begin{array}{l}\text { Knee } \\
\text { Ankle }\end{array}$ & 60 & Positive & $\begin{array}{l}\text { Arthrotomy and } \\
\text { drainage }\end{array}$ & 1 & $\begin{array}{l}\text { 1. Ceftazidime } \\
\text { 2. Doxycycline } \\
\text { 3. Co-trimoxazole }\end{array}$ & $\begin{array}{l}6 \text { weeks } \\
20 \text { weeks } \\
39 \text { weeks }\end{array}$ & 48 \\
\hline 25 & 45 & M & - & Knee & 14 & - & $\begin{array}{l}\text { Arthrotomy and } \\
\text { drainage }\end{array}$ & 1 & $\begin{array}{l}\text { 1. Ceftazidime } \\
\text { 2. Co-trimoxazole }\end{array}$ & $\begin{array}{l}6 \text { weeks } \\
12 \text { weeks }\end{array}$ & 120 \\
\hline 26 & 45 & M & $\begin{array}{l}\text { Spleen } \\
\text { Lungs }\end{array}$ & $\begin{array}{l}\text { Femur } \\
\text { Spleen }\end{array}$ & 180 & Negative & $\begin{array}{l}\text { Decompression and } \\
\text { curettage }\end{array}$ & 3 & $\begin{array}{l}\text { 1. Ceftazidime } \\
\text { 2. Doxycycline } \\
\text { 3. Co-trimoxazole }\end{array}$ & $\begin{array}{l}12 \text { weeks } \\
27 \text { weeks } \\
24 \text { weeks }\end{array}$ & 20 \\
\hline
\end{tabular}
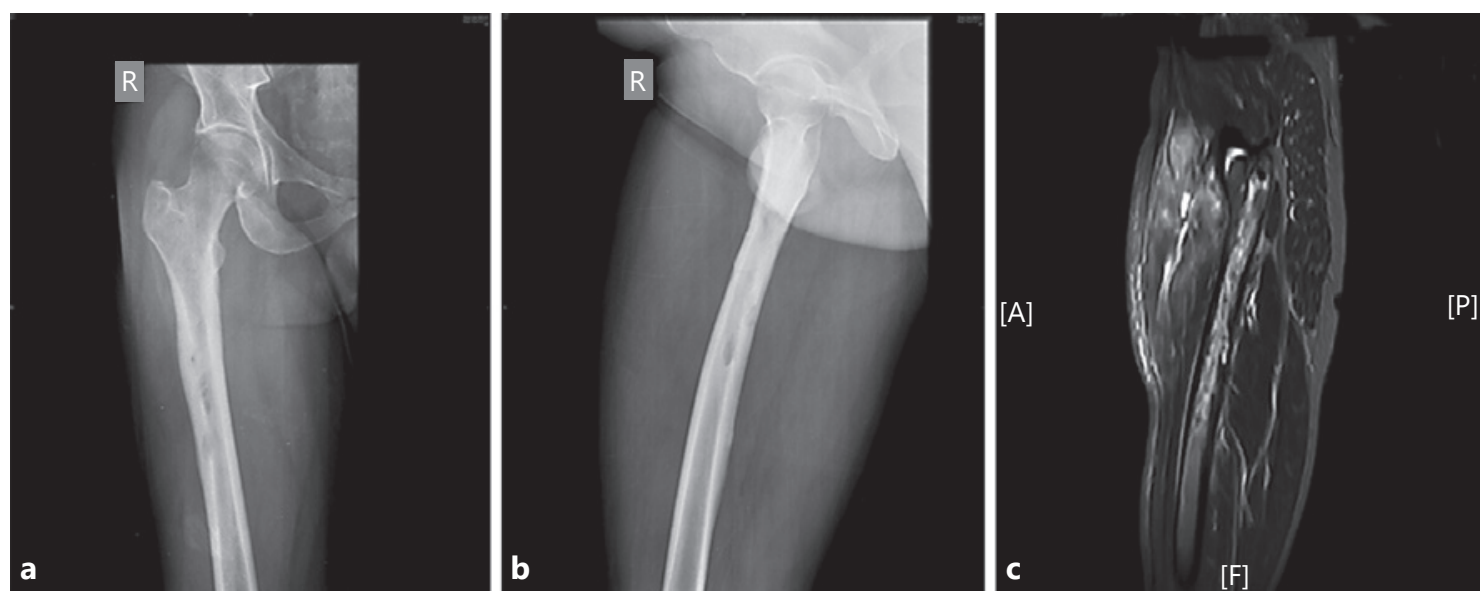

Fig. 2. Preoperative anteroposterior (a) and lateral (b) radiographs and STIR sagittal MRI (c) of the right femur of a 38-year-old man (patient 13, Table 1) with right proximal thigh pain and swelling for 3 weeks associated with low-grade intermittent fever. He was diagnosed with acute chronic osteomyelitis, which was microbiologically confirmed as Burkholderia psuedomallei infection. A year prior to presentation, he was diagnosed and treated elsewhere for Pseudomonas osteomyelitis.

In addition to medical management with antibiotics, all patients required surgical intervention. Deep intraoperative cultures were performed for all patients, and these cultures confirmed B. pseudomallei infection. Histopathological evaluation of the operative surgical specimen was performed for 15 patients (58\%). In 12 patients (46\%), the microscopic lesion was acute inflammatory suppuration, consistent with pyogenic infection. A granulomatous microscopic lesion resembling the lesion in tuberculosis was noted in 3 patients (20\%). A range of orthopaedic surgical procedures were performed to treat the infection (Table 1).
Soft tissue abscesses were incised and drained. Septic arthritis was surgically managed by arthrotomy and drainage. Patients with osteomyelitis underwent debridement and curettage of the bone. In addition, 6 patients (23\%) were also treated with meropenem- or ceftazidime- loaded bone cement for local drug delivery (Fig. 2, 3). Multiple surgical procedures (a maximum of three procedures) were performed in 11 patients (42\%) (Fig. 4, 5). Pathological fractures that required additional operative intervention were seen in 3 patients (11\%). At the final followup, all study patients were found to be free of the disease. 

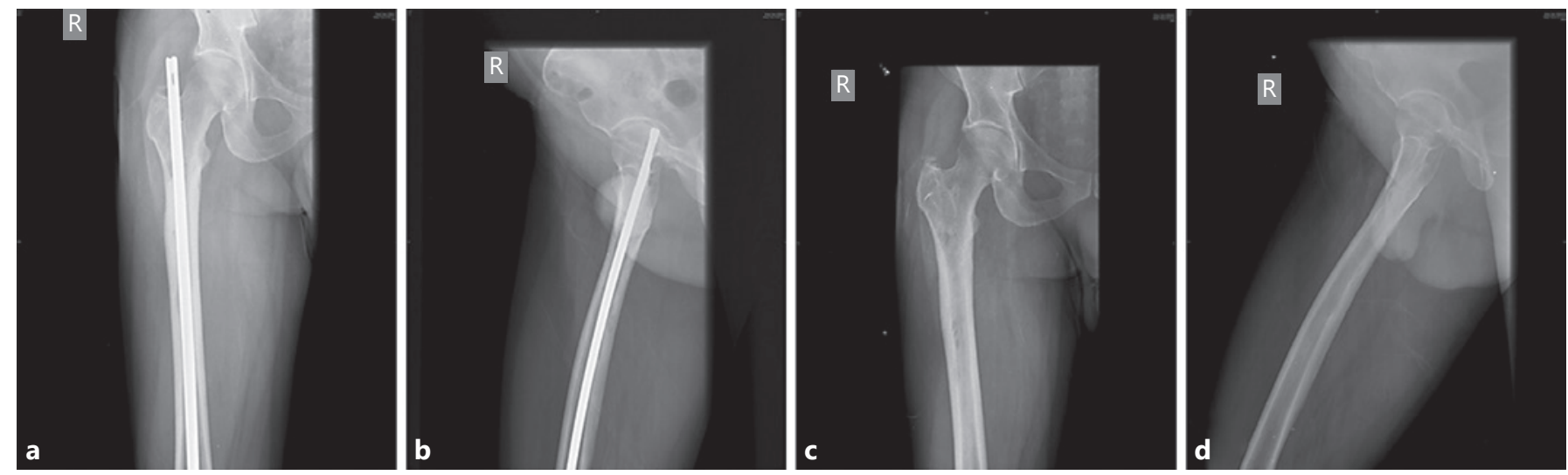

Fig. 3. Postoperative anteroposterior (a) and lateral (b) radiographs of a 38-year-old man (patient 13, Table 1) with melioidosis of the right proximal femur treated through decompression, curettage, antibiotics (meropenem), and bone cement (polymethylmethacrylate)-coated K-nail insertion. There was clinical resolution of the infection, and the patient underwent removal of the implant 4 months later. Anteroposterior (c) and lateral (d) radiographs at the final follow-up 2 years later.
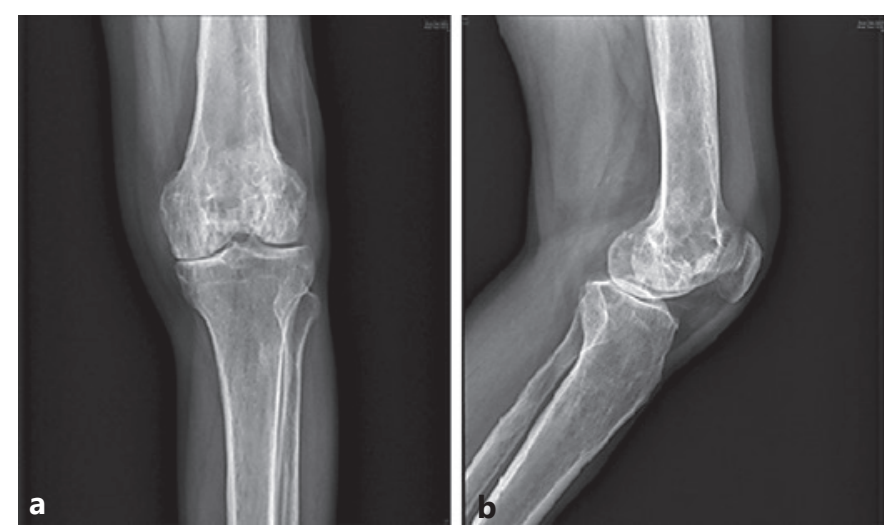

Fig. 4. Anteroposterior (a) and lateral (b) radiographs of a 36-year-old man (patient 16, Table 1) with melioidosis presenting with fever and painful swelling for 14 weeks and right ankle for 3 weeks. Radiographs showed a permeative pattern of bone destruction in the left distal femur and proximal tibia. STIR coronal (c) and sagittal (d) MRI sections showed multiple interosseous collections in the medullary canal of the distal femur and

\section{Discussion}

Though musculoskeletal melioidosis is a well-recognised entity, it is rare even in endemic areas [7]. In our study of 26 patients with musculoskeletal melioidosis, 30 and $11.5 \%$ of patients had multifocal musculoskeletal and multisystemic involvement, respectively. Punyagupta et al. [11] classified melioidosis based on clinical assessment. According to their classification, 19, 2, and 5 of our patients had localised, disseminated, and septicaemic melioidosis, respectively.
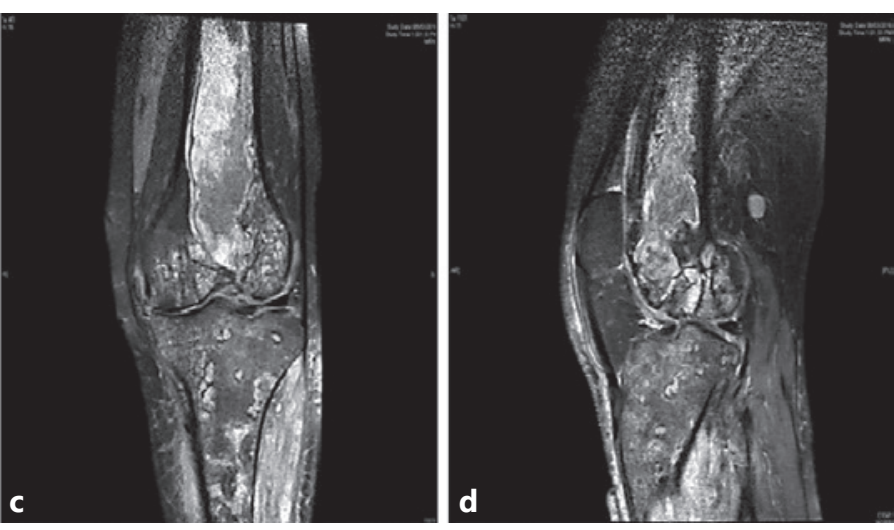

proximal tibia, consistent with infective pathology. He underwent decompression and curettage of the left distal femur and proximal tibia and arthrotomy of the right ankle joint. Five weeks after index surgery, the bone defect was packed with the antibiotic bone cement (ceftazidime), and a soft tissue cover was provided by raising a medial gastrocnemius flap and split thickness skin graft.

The majority of our patients (60\%) presented with symptoms for more than 6 weeks. Nonspecific clinical, radiological, and histopathological features were considered to be reasons for the delay in diagnosis. The biopsy reports of 5 patients were inconclusive and were suggestive of tuberculosis; however, their wound culture was positive for $B$. pseudomallei. With tuberculosis being common in India, some patients undergo empirical treatment for tuberculosis because of lack of definitive diagnosis [12]. Three of our patients had received prior empirical anti-tubercular therapy emphasising

Med Princ Pract 2020;29:121-127 
Fig. 5. Anteroposterior (a) and lateral (b) radiographs of a 36-year-old man (patient 16 , Table 1) with melioidosis that were taken at the final follow-up (30 months) showing an antibiotic bone cement (polymethylmethacrylate) spacer in the bone defect of the left proximal tibia. The patient had no recurrence at final follow-up.
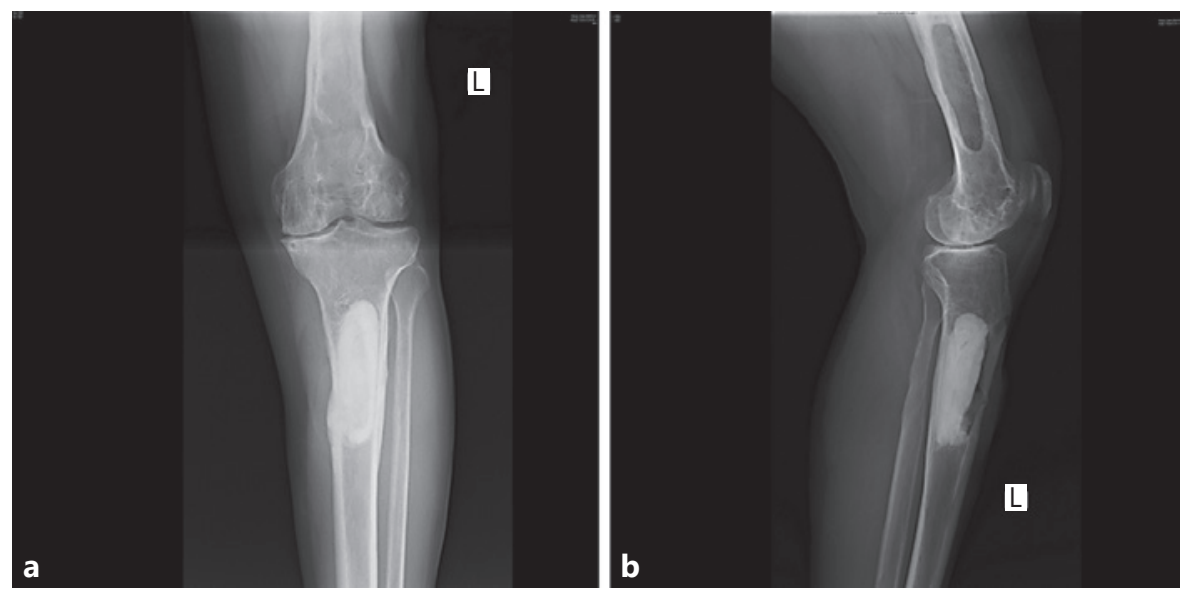

the need to consider $B$. pseudomallei as a differential diagnosis in a setting that mimics skeletal tuberculosis [12].

More than three quarters of our patients had medical comorbidities, with diabetes being the most common. Shetty et al. [13] in their review of 50 patients with musculoskeletal melioidosis also reported that $80 \%$ of their patients had one or more comorbidities with diabetes being the most common. Kosuwon et al. [14] in their retrospective review on 25 patients with meliodotic septic arthritis also highlighted the increased association of melioidosis with diabetes. Diabetes impairs neutrophil functions, such as mobilisation, delivery, adherence, and ingestion, and is known to be associated with melioidosis $[15,16]$. Microscopically, the histopathological lesion in melioidosis has been reported to form a spectrum from suppurative inflammation in acute illness to caseous granulomatous inflammation, similar to chronic tuberculosis $[6,17]$. Although most of our patients presented with symptoms of duration greater than 6 weeks, granuloma formation was noted in only 3 patients. The histopathological findings of the remaining patients were suggestive of inflammatory suppuration, with no evidence of granuloma formation. Therefore, a granulomatous histological appearance cannot be relied upon to confirm the diagnosis, even in chronic cases of melioidosis.

Musculoskeletal melioidosis may present as septic arthritis, osteomyelitis, or soft tissue abscess $[13,18]$. The varied clinical presentation necessitated a range of orthopaedic procedures (Table 1). All 26 patients required surgical treatment along with a full course of antibiotics. The use of local antibiotic delivery with antibiotic-loaded bone cement beads or calcium hydroxyapatite for the treatment of musculoskeletal infections has been well de- scribed [19]. We used meropenem- or ceftazidime-loaded polymethylmethacrylate bone cement as a local drug delivery agent to successfully treat musculoskeletal melioidosis in 6 of our patients. Prolonged treatment and the need for multiple surgical interventions observed in our series highlight the clinical burden of treating this infection. Morse et al. [18] reviewed 20 patients with musculoskeletal melioidosis and noted that while appropriate intravenous antibiotics are important, adequate surgical drainage and debridement are vital. Subhadrabandhu et al. [20] and more recently Pandey et al. [21] have published their series of 10 and 5 patients, respectively, highlighting their treatment strategy of surgical debridement in addition to antibiotics to successfully treat all their patients. Shetty et al. [13] noted that most patients with musculoskeletal melioidosis needed operative intervention and those with multifocal bone and joint involvement needed significantly longer hospital stay and more operations.

Our study, being retrospective in nature, has limitations inherent to an observational clinical series, such as misclassification bias and medical record abstraction errors [22]. However, melioidosis is a rare disease, and the importance of retrospective observational studies conducted using pre-existing data for studying rare medical disorders is well established [22].

\section{Conclusion}

The rate of musculoskeletal involvement in B. pseudomallei infection was $9.2 \%$. Varied clinical presentation and multifocal involvement necessitated a range of surgical procedures which, in combination with antibiotic therapy, was successful in the resolution of the infection. 


\section{Acknowledgements}

The authors thank Dr. John Antony Jude Prakash and Susmitha Karunasree Perumalla, Department of Microbiology, Christian Medical College, Vellore, for their help with manuscript preparation.

\section{Disclosure Statement}

The authors have no conflict of interest to declare.

\section{Funding Sources}

No funding was received for this study.

\section{Author Contributions}

Rajamani Perumal: data collection, manuscript writing, and patient care. Abel Livingston: data collection and manuscript writing. Sumant Samuel: manuscript writing, editing, and patient care. Santhosh Kumar Govindaraju: data collection and patient care.

\section{References}

1 Whitmore A, Krishnaswami CS. A Hitherto undescribed infective disease in Rangoon. Ind Med Gaz. 1912 Jul;47(7):262-7.

2 Jesudason MV, Anbarasu A, John TJ. Septicaemic melioidosis in a tertiary care hospital in south India. Indian J Med Res. 2003 Mar; 117:119-21.

3 Chrispal A, Rajan SJ, Sathyendra S. The clinical profile and predictors of mortality in patients with melioidosis in South India. Trop Doct. 2010 Jan;40(1):36-8.

4 Mukhopadhyay C, Dey A, Sugandhi Rao P, Pandey V, Sripathi Rao P. Aetiology and management of chronic granulomatous osteomyelitis: look before you leap. Singapore Med J. 2007 Feb;48(2):e40-2.

5 Kärcher AM, Zaman A, Brewis C, Fahmy T. Neck lumps: expect the unexpected. Lancet. 2000 Mar;355(9209):1070.

6 John TJ, Jesudason MV, Lalitha MK, Ganesh A, Mohandas V, Cherian T, et al. Melioidosis In India: the tip of the iceberg? Indian J Med Res. 1996 Jan;103:62-5.

7 Vidyalakshmi K, Lipika S, Vishal S, Damodar S, Chakrapani M. Emerging clinico-epidemiological trends in melioidosis: analysis of 95 cases from western coastal India. Int J Infect Dis. 2012 Jul;16(7):e491-7.

8 Tille PM. Bailey \& Scott's diagnostic microbiology. 14th ed. St. Louis: Elsevier; 2017.
9 Clinical and Laboratory Standards Institute, editor. Methods for antimicrobial dilution and disk susceptibility testing of infrequently isolated or fastidious bacteria. 3rd ed. Wayne (PA): Clinical and Laboratory Standards Institute; 2016.

10 American Diabetes Association. 2. Classification and Diagnosis of Diabetes: Standards of Medical Care in Diabetes-2018. Diabetes Care. 2018 Jan;41(Suppl 1):S13-27.

11 Punyagupta S. Melioidosis. Review of 686 cases and presentation of a new clinical classification. In: Punyagupta S, Sirisanthana T, Stapatayavong, editors. Melioidosis. Bangkok: Bangkok Medical Publisher; 1989. pp.217-29.

12 Vidyalakshmi K, Chakrapani M, Shrikala B, Damodar S, Lipika S, Vishal S. Tuberculosis mimicked by melioidosis. Int J Tuberc Lung Dis. 2008 Oct; 12(10):1209-15.

13 Shetty RP, Mathew M, Smith J, Morse LP, Mehta JA, Currie BJ. Management of melioidosis osteomyelitis and septic arthritis. Bone Joint J. 2015 Feb;97-B(2):277-82.

14 Kosuwon W, Taimglang T, Sirichativapee W, Jeeravipoolvarn P. Melioidotic septic arthritis and its risk factors. J Bone Joint Surg Am. 2003 Jun;85(6):1058-61.
15 Marhoffer W, Stein M, Maeser E, Federlin K. Impairment of polymorphonuclear leukocyte function and metabolic control of diabetes. Diabetes Care. 1992 Feb;15(2):256-60.

16 Jones AL, Beveridge TJ, Woods DE. Intracellular survival of Burkholderia pseudomallei. Infect Immun. 1996 Mar;64(3):782-90.

17 Raghavan KR, Shenoi RP, Zaer F, Aiyer R, Ramamoorthy P, Mehta MN. Melioidosis in India. Indian Pediatr. 1991 Feb;28(2):184-8.

18 Morse LP, Smith J, Mehta J, Ward L, Cheng AC, Currie BJ. Osteomyelitis and septic arthritis from infection with Burkholderia pseudomallei: A 20-year prospective melioidosis study from northern Australia. J Orthop. 2013 May; 10(2):86-91.

19 Hanssen AD. Local antibiotic delivery vehicles in the treatment of musculoskeletal infection. Clin Orthop Relat Res. 2005 Aug;(437):91-6.

20 Subhadrabandhu T, Prichasuk S, Sathapatayavongs B. Localised melioidotic osteomyelitis. J Bone Joint Surg Br. 1995 May;77(3):445-9.

21 Pandey V, Rao SP, Rao S, Acharya KK, Chhabra SS. Burkholderia pseudomallei musculoskeletal infections (melioidosis) in India. Indian J Orthop. 2010 Apr;44(2):216-20.

22 Kooistra B, Dijkman B, Einhorn TA, Bhandari M. How to design a good case series. J Bone Joint Surg Am. 2009 May;91 Suppl 3: 21-6. 